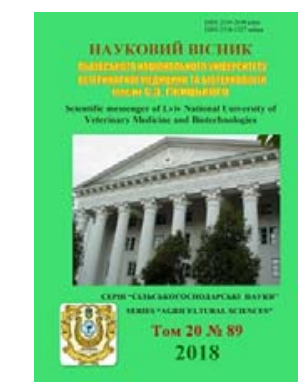

Науковий вісник Дьвівського національного університету ветеринарної медицини та біотехнологій імені С.3. Гжицького

\author{
Scientific Messenger of Lviv National University \\ of Veterinary Medicine and Biotechnologies
}

\title{
Analysis of the dynamics of changes in the ecological state of surface waters of the Busk district
}

\author{
O.V. Matsuska, O.P. Sukhorska, Ya.M. Chaban \\ Stepan Gzhytskyi National University of Veterinary Medicine and Biotechnologies Lviv, Ukraine
}

Article info

Received 11.09.2018

Received in revised form 15.10 .2018

Accepted 16.10.2018

Stepan Gzhytskyi National University of Veterinary Medicine and Biotechnologies Lviv, Pekarska Str., 50, Lviv, 79010, Ukraine.

Tel.: +38-067-25-99-539

E-mail:kasanam@meta.ua
Matsuska, O.V., Sukhorska, O.P., \& Chaban, Ya.M. (2018). Analysis of the dynamics of changes in the ecological state of surface waters of the Busk district. Scientific Messenger of Lviv National University of Veterinary Medicine and Biotechnologies, 20(89), 79-84. doi: 10.32718/nvlvet8915

On the basis of the generalization and systematization of the results of the regime observations made by environmental monitoring services it has been made an ecological assessment of the water quality in the Ukrainian part of the Western Bug River basin (in six section lines of observation). It has been found, the largest source of mechanical contaminations, organic pollutants and nutrients in the Western Bug River is the river Poltva. That is why insufficiently treated waste water of Lviv increases the level of water pollution in this Basin. Main focus is concentrated on the river Western Bug and its stream tributary (the Poltva river), which significantly affects its ecological status. The data concerning pollution indicators for 20152018 years was analyzed. A comparison characteristics of the change of pollution of the investigated water objects is carried out in three lookout points: in the river Poltva before falling into the river Western Bug, in the river Western Bug (background area) the above-fall of the Poltva River, in the river Western Bug the below-fall of the Poltva River. Exceeding of the permitted values of most indicators was detected in 2017: suspended matters - 2.4 MPC, ammonium nitrogen - 8.7 MPC, phosphates - 8MPC, low level of dissolved oxygen is observed, because of high content of organic matters. This situation is better in the basin of the Western Bug River in the sampled area in 2018. The water of the Poltva River is much cleaner in comparison to the previous year, containing up to 2.3 times less suspended substances, 5.1 times less phosphates and 1.3 times organic substances. In this year there is a significant improvement in the ecological state of the Western Bug River, after the falling into the Poltva River. The ecological state of water of these water basins depends on the efficiency of the treatment facilities, especially in Lviv. Municipal wastewater treatment facilities have undergone repair works over recent years in Lviv.

Key words: surface waters, basin of the Western Bug, Poltva river, ecological assessment, monitoring, pollution, dynamic.

\section{Аналіз динаміки зміни екологічного стану поверхневих вод Буського району}

\author{
О.В. Мацуська, О.П. Сухорська, Я.М. Чабан
}

Львівський національний університет ветеринарної медицини та біотехнологій імені С.3. Гжицького, м. Львів, Украӥна

На підставі узагальнення та систематизації результатів режимних спостережень служб моніторингу за станом довкілля здійснено екологічну оцінку стану басейну річки Західного Бугу на території Украӥни (у 6 створах спостереження). Встановлено, що найбільшим джерелом внесення механічних домішок, органічних забруднень та біогенних елементів в ріку Західний Буг є річка Полтва. Саме тому, недостатньо очищені стічні води міста Львова підвишують рівень забруднення води в иьому басейні. Основна увага зосереджена на річці Західний Буг та ї̈ притоці р. Полтві, щуо істотно впливає на екологічний стан басейну, у який впадає. Проаналізовано дані за основними показниками щодо їх забруднення, протягом 2015-2018 років. 3дійснено порівняльну характеристику зміни забруднення досліджуваних водних об'єктів, у трьох пунктах спостереження: у річці Полтві, перед впадінням у річку Західний Буг; у річиі Західний Буг (фонова ділянка), вище впадіння річки Полтви; у річці Західний Буг, нижче впадіння річки Полтви. Перевищення допустимих значень більшості показників виявлено у 2017 рочі: завислих речовин 2,4 ГДК, амонію 8,7 
ГДК, фосфатів 8 ГДК, спостерігається низький вміст розчиненого кисню, який підтверджується високим показником БСК $~$ 5,5 ГДК. Значно кращзю на досліджуваній території є ситуація у басейні річки Західний Буг у 2018 р.

Ключові слова: поверхневі води, басейн Західного Бугу, річка Полтва, моніторинг, екологічна оцінка, забруднення, динаміка.

Вступ

Екологічний стан поверхневих вод Львівщини й надалі залишається у незадовільному стані. Основними проблемами забруднення $є$ скид неочищених та недостатньо очищених стічних вод, а також відсутність водоохоронних зон і прибережно-захисних смуг водних об'єктів.

Скид неочищених та недостатньо очищених комунальних і промислових стоків відбувається через фізичний та моральний знос очисних споруд і відсутністю коштів на будівництво, ремонт та їхню реконструкцію. Внаслідок тривалої експлуатації без необхідного поточного ремонту систем водопостачання і каналізації більшість водопровідно-каналізаційних господарств області перебувають у незадовільному технічному стані, який щодня погіршується, частина 3 них в аварійному стані (Shandrovych et al., 2015; Shandrovich and Mal'ovanyj, 2015).

Оцінка якості природних вод має важливе значення для наукових досліджень і практичних потреб, оскільки дає змогу раціонально використовувати водні об'єкти та забезпечити їх охорону від забруднення, а особливо, коли йде мова про транскордонні ріки. Водні ресурси басейну р. Західний Буг використовує не тільки Україна, а й Польща та Білорусія. Ця ріка є транскордонним об'єктом і згідно з програмою транскордонного співробітництва "Польща-БілорусьУкраїна”, Україна зобов'язана контролювати стан басейну річки Західний Буг та іiі приток (Klymenko and Vozniuk, 2011; Klymenko et al., 2012; Mudryk et al., 2016).

Аналіз динаміки зміни екологічного стану р. Західний Буг, а особливо під впливом іiі найбруднішої притоки - р. Полтви, є першим кроком на шляху збереження водних ресурсів. Чимало наукових праць присвячено цій проблемі (Klymenko and Vozniuk, 2011; Gumnitsky et al., 2013; Stadnichuk et al., 2013; Mudryk et al., 2016).

\section{Матеріал і методи досліджень}

Основні обсяги поверхневих вод області формуються в річках. За даними Львівського Держводагенства, в області налічується понад 8950 річок. Найбільше їх належить до басейнів Дністра (5738), Західного Бугу (3213) і незначна частина - до басейну Сяну та Прип'яті (Стир) (Stadnichuk et al., 2013; Iakisnyi stan poverkhnevykh vod Lvivskoi oblasti u 2016 r).

Спостереження за станом поверхневих вод Львівської області здійснюють: Державна екологічна інспекція в Львівській області; Львівське обласне виробниче управління водного господарства; Львівська обласна санітарно-епідеміологічна станція; Волинський обласний центр $з$ гідрометеорології; Рівненський обласний центр з гідрометеорології.
Лабораторія моніторингу вод та грунтів Львівської ГГМЕ щоквартально аналізує якість поверхневих вод області у 17 створах, з яких 6 - у басейні Західного Бугу, решта - у басейнах Дністра та Сяну.

Протягом 2016 року водокористувачами Львівської області було скинуто в поверхневі водні об'єкти 206,2 млн м ${ }^{3}$ зворотних вод. У порівнянні з 2015 p. загальний скид стоків зменшився на 1,5 млн $\mathrm{M}^{3}$ відповідно до зменшення забору води 3 природних водних об'єктів. Об'єми забруднених стічних вод у звітному році, зросли на 1,08 млн м ${ }^{3}\left(46,08\right.$ млн м $\left.{ }^{3}\right)$. Скиди нормативно-очищених вод збільшились на 0,5 млн м $^{3}$ (144,3 млн м м $^{3}$, а нормативно-чистих вод зменшились на 3,12 млн м³ $\left(15,72\right.$ млн м ${ }^{3}$ ) (Klymenko et al., 2012).

Проаналізовано звіти про результати моніторингу стану навколишнього природного середовища Львівщини, зокрема, що стосується басейну річки Західний Буг, за період 2015-2018 років (Mudryk et al., 2016; Chaban, 2018).

\section{Результати та їх обговорення}

1. Аналіз якісного стану басейну р. Західний Буг. Головними напрямками водокористування в басейні p. Західний Буг є забезпечення населення питною водою, а також водозабезпечення промисловості та сільського господарства достатньою кількістю води необхідної якості. Проте відомо, що під впливом господарської діяльності територія басейну даного водного об’єкту зазнала значної антропогенної трансформації (табл. 1).

Як видно із даних табл. 1, вода у р. Полтві характеризується як “дуже брудна" та спостерігається погіршення іiі якості 2016 р порівняно із попереднім роком. Аналогічною є ситуація, що склалась за звітні роки і у створах “р. Західний Буг - м. Кам'янкаБузька" та “p. Західний Буг - м. Добротвір", хоча вода у них відзначається як "помірно забруднена", а в пунктах спостережень "p. Західний Буг - м. Сокаль”, “p. Західний Буг - с. Старгород” і в р. Раті - “слабко забруднена". Порівняно з попереднім роком ситуація практично не змінилась, хіба що у шостому створі якість води дещо поліпшилась.

Аналіз моніторингових досліджень вказує на те, що після впадіння p. Полтви (яка $\epsilon$ колектором стічних вод м. Львова) протягом десятків кілометрів, якість води Західного Бугу є незадовільною. Техногенний вплив підсилюється також і досить розвинутою діяльністю даного району (Klymenko and Vozniuk, 2011; Mudryk et al., 2016).

У воді р. Полтви спостерігається високий вміст $Б^{\circ} K_{5}$, що $\sim$ у 20 разів перевищує його допустиму норму. Це вказує на високу концентрацію органічних речовин у ній, в результаті окислення яких затрачається кисень (в 4 рази нижче допустимого рівня). 


\section{Таблищя 1}

Оцінка якісного стану басейну річки Західного Бугу (Klymenko et al., 2012; Iakisnyi stan poverkhnevykh vod Lvivskoi oblasti u 2016 r)

\begin{tabular}{|c|c|c|c|c|}
\hline \multirow{2}{*}{$\begin{array}{c}\text { № } \\
\text { ח/п }\end{array}$} & \multirow{2}{*}{$\begin{array}{c}\text { Місце розташування } \\
\text { створу }\end{array}$} & \multicolumn{2}{|c|}{ Якісний стан басейну річки Західний Буг } & \multirow{2}{*}{$\begin{array}{c}\text { Характеристика води у } \\
\text { створі (згідно КНД } \\
211.1 .1 .106-2003) \text { та } \\
\text { оцінка факторів впливу } \\
\text { на неї } \\
\end{array}$} \\
\hline & & y 2016 p & $\begin{array}{l}\text { Порівняно } \\
\text { iз } 2015 \mathrm{p}\end{array}$ & \\
\hline 1. & $\begin{array}{l}\text { Права притока - } \\
\text { p. Полтва, } \\
\text { с. Кам'янопіль (ни- } \\
\text { жче очисних споруд) }\end{array}$ & $\begin{array}{l}\text { Низький вміст розчиненого } \\
\text { кисню }\left(0,9-1,3 \text { мгО } 2 / \text { дм }^{3}, \text { при }\right. \\
\left.\text { ГДК } \geq 4 \text { мГО }_{2} / \text { дм }^{3}\right), \text { БСК }-17,8- \\
21,2 \text { ГДК, ХСК }-6,1-6,5 \text { ГДК, } \\
\text { амоній - 6,1-23,3 ГДК, нітрити } \\
-4,5-15 \text { ГДК, фосфати - 14,9- } \\
27,9 \text { ГДК, залізо - 2,8-5 ГДК і } \\
\text { сульфати (у незначній мірі) }\end{array}$ & $\begin{array}{l}\text { Погіршився за показника- } \\
\text { ми БСК5 і ХСК, вмістом } \\
\text { розчиненого кисню, фос- } \\
\text { фатів і амонію, однак зни- } \\
\text { зилася } \\
\text { нітратів. онцентрація } \\
\text { мінералізація води }\end{array}$ & $\begin{array}{l}\text { “Дуже брудна” } \\
\text { Вплив стічних вод } \\
\text { м. Львова }\end{array}$ \\
\hline 2. & $\begin{array}{l}\text { p. Західний Буг, } \\
\text { м. Кам’янка Бузька }\end{array}$ & $\begin{array}{l}\text { БСК5 - } 2 \text { ГДК, ХСК (в незначній } \\
\text { мірі), амоній - 5,9-7,8 ГДК, } \\
\text { нітрити - 7-10,3 ГДК, фосфати } \\
-4,5-11,6 \text { ГДК, залізо - 5,9 ГДК }\end{array}$ & $\begin{array}{l}\text { Якість води в створі погір- } \\
\text { шилася за вмістом розчи- } \\
\text { неного кисню, амонію, } \\
\text { нітритів і заліза, однак } \\
\text { знизилася концентрація } \\
\text { нітратів }\end{array}$ & $\begin{array}{l}\text { “Помірно забруднена”; } \\
\text { Вплив стічних вод } \\
\text { КП “Львівводоканал” } \\
\text { через р. Полтву та Бусь- } \\
\text { кого ВУГК }\end{array}$ \\
\hline 3. & $\begin{array}{l}\text { p. Західний Буг, } \\
\text { м. Добротвір (нижче } \\
\text { Добротвірського } \\
\text { водосховища) }\end{array}$ & $\begin{array}{l}\text { Від створу в м. Кам'янці- } \\
\text { Бузькій якість води поліпшила- } \\
\text { ся за вмістом розчиненого } \\
\text { кисню, амонію }(4,5-5,8 \text { ГДК), } \\
\text { заліза (2,4 ГДК) і завислих } \\
\text { речовин, нітратів (7-9 ГДК), } \\
\text { проте підвищилася концентра- } \\
\text { ція фосфатів (7,6-17,5 ГДК). } \\
\text { Виявлено перевищення показ- } \\
\text { ника БСК - } 2 \text { ГДК, Міне- } \\
\text { ралізація води знизилася }\end{array}$ & $\begin{array}{l}\text { Якість води погіршилась за } \\
\text { вмістом амонію, нітритів, } \\
\text { нітратів і фосфатів, проте } \\
\text { знизилася концентрація } \\
\text { завислих речовин }\end{array}$ & $\begin{array}{l}\text { “Помірно забруднена”; } \\
\text { Можливий } \\
\text { стічних вод вплив } \\
\text { ПАТ “'Західенерго” і } \\
\text { КП “Кам’янкаводоканал” }\end{array}$ \\
\hline 4. & $\begin{array}{l}\text { Ліва притока - } \\
\text { Західного Бугу, } \\
\text { р. Рата, смт. Великі } \\
\text { Мости }\end{array}$ & $\begin{array}{l}\text { Найкраща якість води у басейні. } \\
\text { Не значне перевищення показ- } \\
\text { ника БСК5, фосфатів - } 2,4 \text { ГДК, } \\
\text { заліза - 4,4 ГДК і нітритів - } \\
2 \text { ГДК }\end{array}$ & $\begin{array}{l}\text { Якість води суттєво не } \\
\text { змінилася }\end{array}$ & 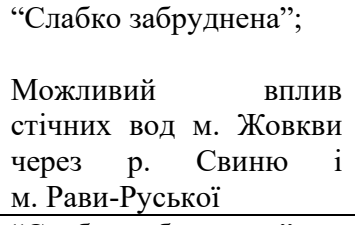 \\
\hline 5. & $\begin{array}{l}\text { p. Західний Буг, } \\
\text { м. Сокаль }\end{array}$ & $\begin{array}{l}\text { Від пункту спостережень в м. } \\
\text { Добротворі до створу в м. Со- } \\
\text { калі якість води поліпшилася за } \\
\text { показниками БСК (2 ГДК), } \\
\text { ХСК (незначні зміни), вмістом } \\
\text { розчиненого кисню, амонію }(2,6 \\
\text { ГДК), нітритів (2-6,8 ГДК) і } \\
\text { фосфатів (3,9-7,5 ГДК), заліза - } \\
3,2 \text { ГДК і сульфатів. Проте } \\
\text { підвищилася концентрація } \\
\text { завислих речовин }\end{array}$ & $\begin{array}{l}\text { Підвищився вміст фос- } \\
\text { фатів, проте } \quad \text { знизилась } \\
\text { концентрація } \quad \text { нітратів, } \\
\text { загалом якість води суттєво } \\
\text { не змінилася }\end{array}$ & $\begin{array}{l}\text { “Слабко забруднена”; } \\
\text { Вплив стічних вод КП } \\
\text { "Червоноградводоканал” }\end{array}$ \\
\hline 6. & $\begin{array}{l}\text { p. Західний Буг - } \\
\text { с. Старгород }\end{array}$ & $\begin{array}{l}\text { Зафіксовано перевищення по- } \\
\text { казника БСК }-2 \text { ГДК, амонію - } \\
3 \text { ГДК, нітритів - 2,3-8,3 ГДК, } \\
\text { фосфатів - 3,6-7,4 ГДК і заліза } \\
-3 \text { ГДК, незначні перевищення } \\
\text { норм ХСК і сульфатів }\end{array}$ & $\begin{array}{l}\text { Якість води в створі по- } \\
\text { кращилася: підвищилася } \\
\text { концентрація розчиненого } \\
\text { кисню, знизився показник } \\
\text { БСК5, вміст амонію, } \\
\text { нітратів, фосфатів і заліза }\end{array}$ & $\begin{array}{l}\text { “Слабко забруднена”; } \\
\text { Можливий } \\
\text { стічних вод м. Сокаля }\end{array}$ \\
\hline
\end{tabular}

Разом із органічними речовинами, вода річки Полтви вносить у річку Західний Буг в 20 і більше разів вище за норму біогенних елементів - азоту і фосфору, що спричинює явище евтрофікації та деградації цих водних об' єктів.

2. Аналіз змін екологічного стану поверхневих водних об'єктів у Буському районі, за період 2015 2018 рр та оцінка негативного впливу р. Полтви на р. Західний Буг. Аналіз змін екологічного стану p. Західний Буг та іiі притоки р. Полтви, за 20152018 pp і оцінка негативного впливу р. Полтви на p. Західний Буг, за найбільш вагомими показниками забруднення показано на рис. 1-5 (Chaban, 2018).

Як видно із даного рисунка, найвищий вміст завислих речовин у р. Полтві зафіксовано в 2017 році ( 3 ГДК), проте у поточному році, спостерігається його зниження майже вдвічі. 


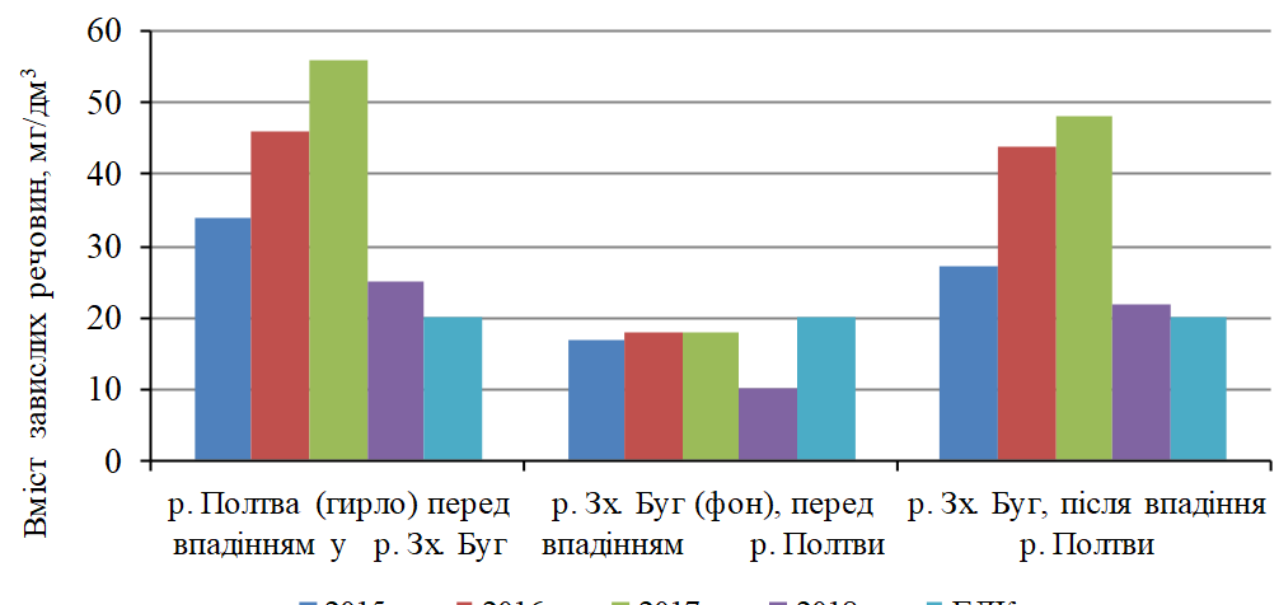

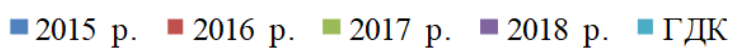

Рис. 1. Динаміка зміни вмісту завислих речовин у водних об'єктах Буського району та оцінка впливу води р. Полтви на стан р. Зх. Буг

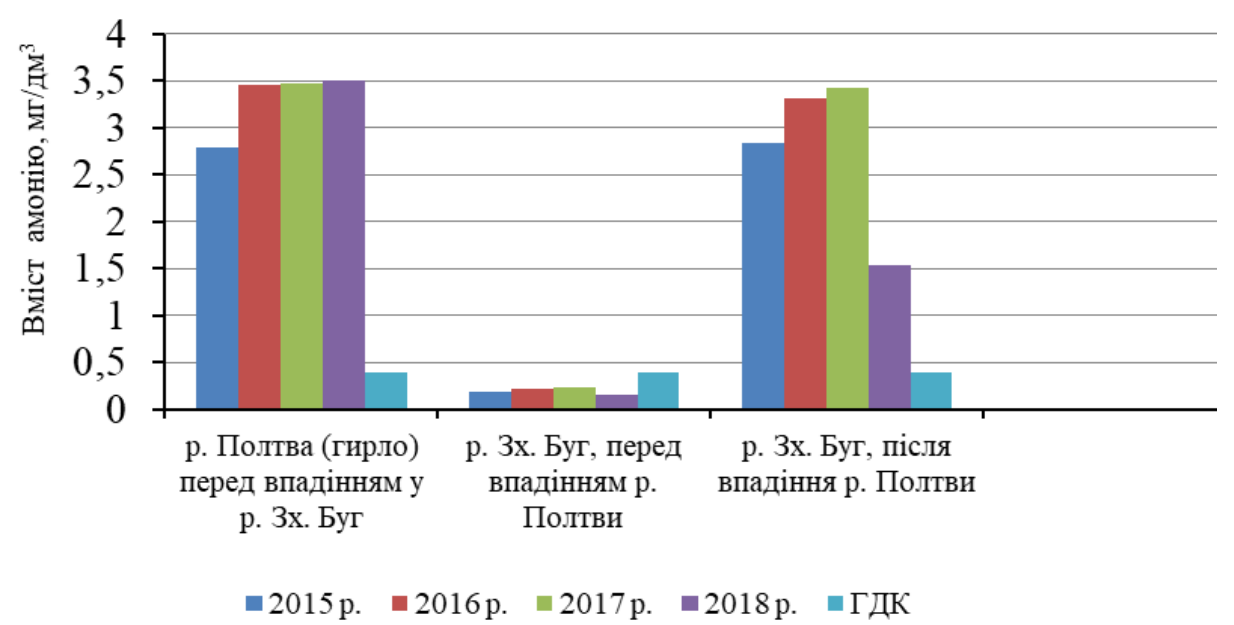

Рис. 2. Динаміка зміни вмісту амонію у водних об'єктах Буського району та оцінка впливу води р. Полтви на стан р. Зх. Буг

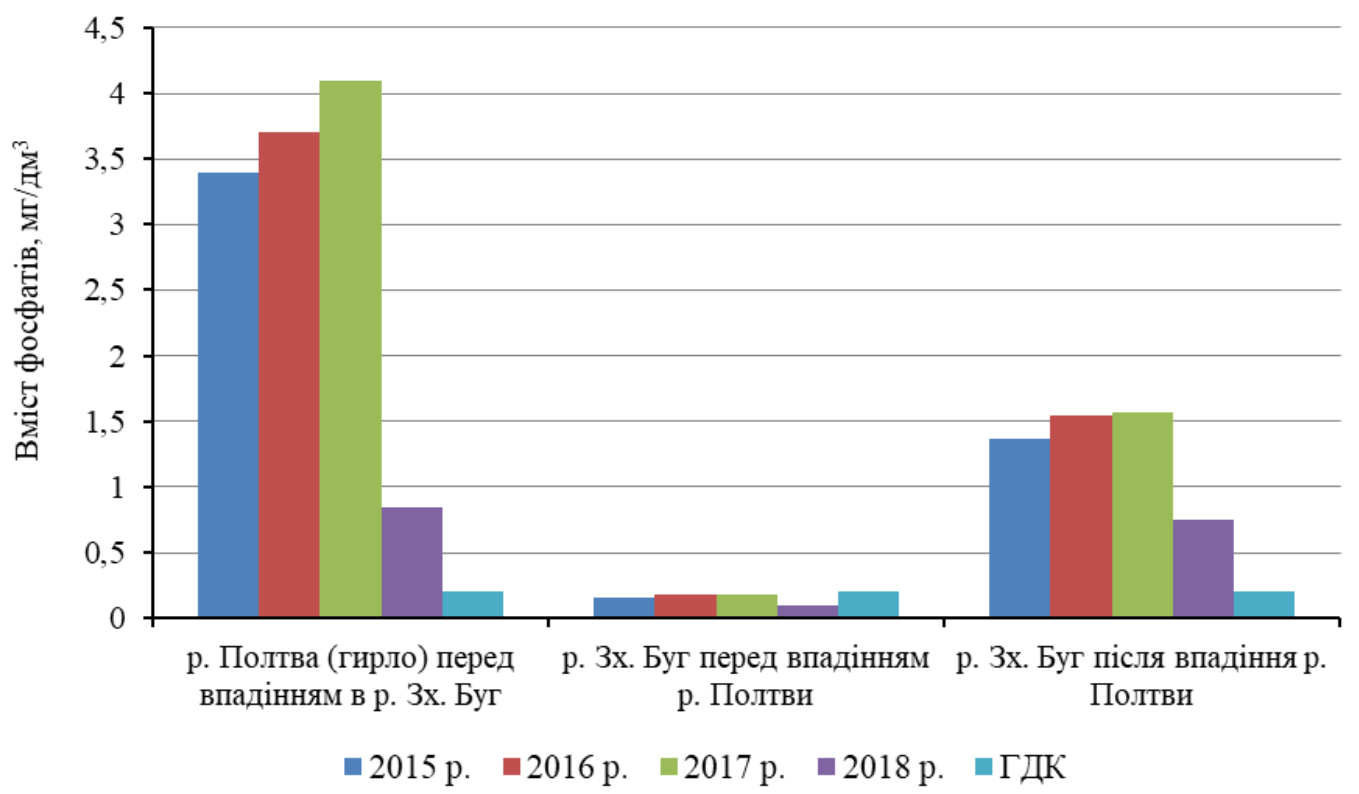

Рис. 3. Динаміка зміни вмісту фосфатів, у водних об'єктах Буського району та оцінка впливу води p. Полтви на стан р. Зх. Буг 
Вода річки Полтви є досить каламутною, і це має безпосередній вплив на басейн у який вона впадає. На фоновій ділянці р. Західного Бугу, тобто до впадіння вод р. Полтви, немає перевищень за завислими речовинами, що змінюється після іiі впадіння, де чітко відстежується закономірність цього негативного впливу.

На відміну від завислих речовин вміст амонію у р. Полтві за останній рік збільшився у 9 разів. Досить високим є вміст цього забрудника у р. Західний Буг після надходження води р. Полтви. I якщо на фоновій ділянці, амонійний азот був вдвічі нижчим за допустимий рівень, то вода р. Полтви змінює ці цифрові значення $\sim$ у 15 разів.

Результати досліджень, показані на рис. 3, вказують про значне зниження вмісту фосфатів ( 5 разів) у 2018 році як у р. Полтві, так і у р. Західний Буг, після iii впадіння ( 2,2 рази). Проте, спостерігається чітка тенденція негативної зміни якості води Західного Бугу за вмістом фосфатів при надходженні води іiі притоки.

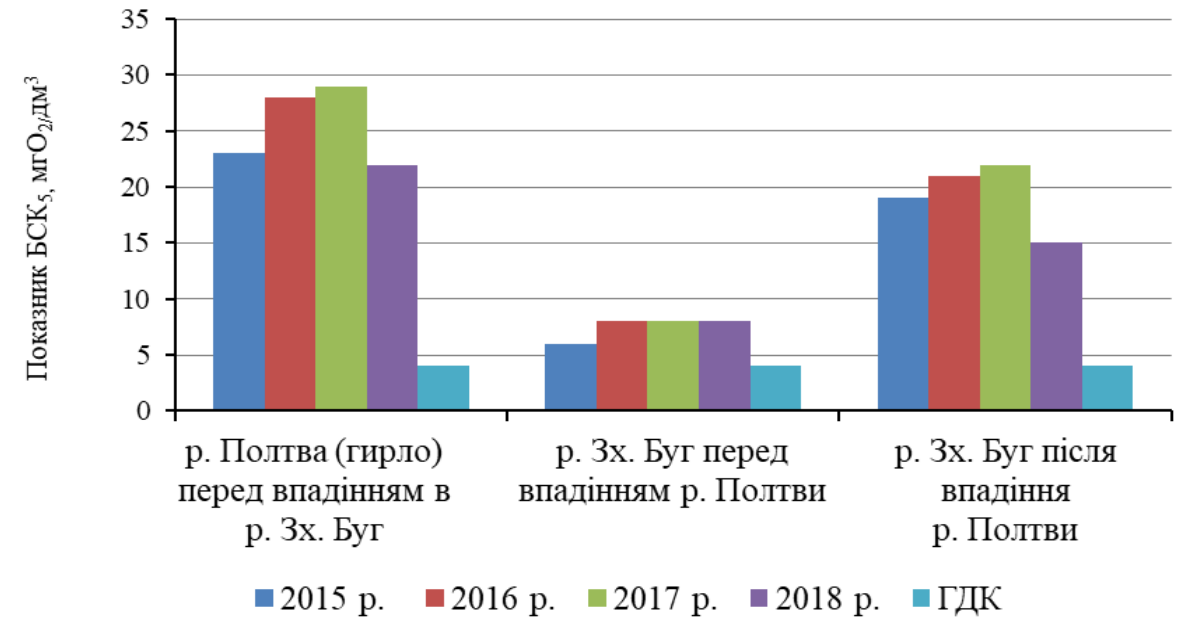

Рис. 4. Динаміка зміни показника БСК 5 у водних об'єктах Буського району та оцінка впливу води p. Полтви на стан р. Зх. Буг

У результаті постійного техногенного навантаження фонова ділянка води у р. Західний Буг містить органічних речовин понад норму, про що говорить перевищення вдвічі показника БСК , за остатні три роки. Даний показник у воді р. Полтви є досить високим, у поточному році - знижується в 1,3 разу. Це позначається на якості води р. Західний Буг.

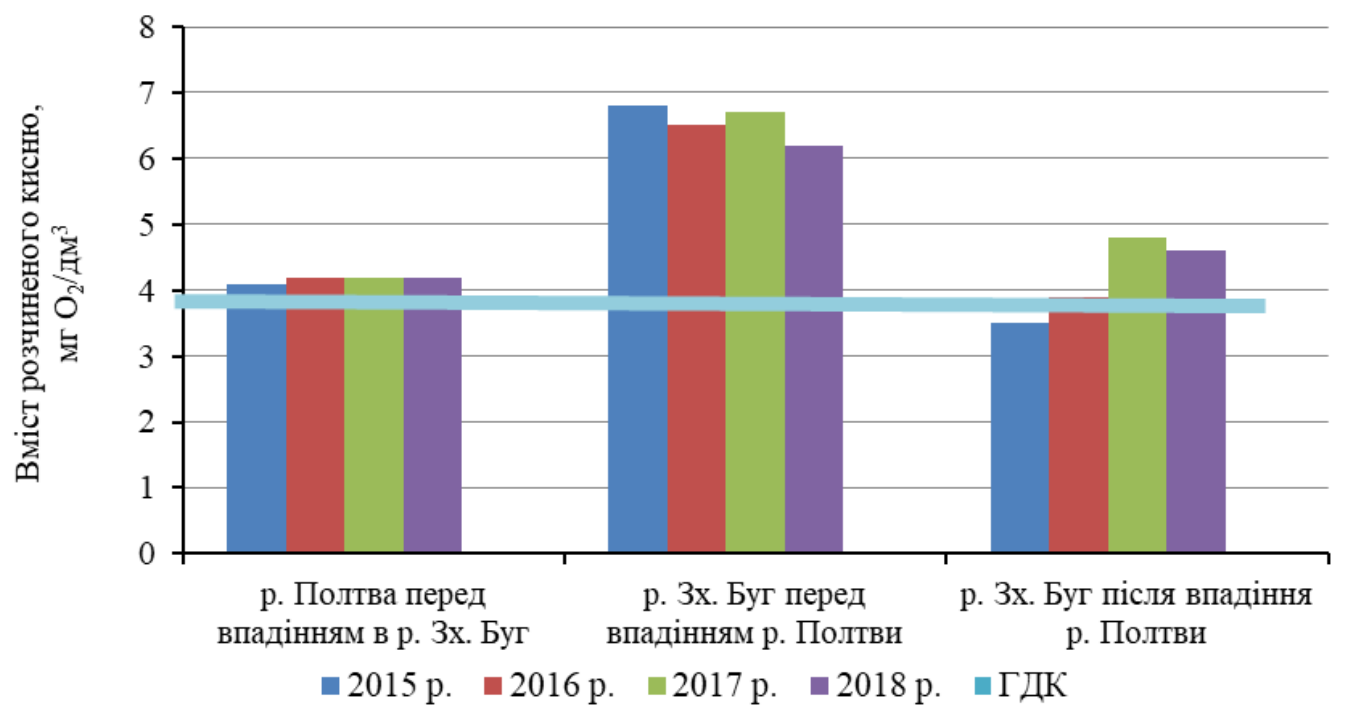

Рис. 5. Динаміка зміни вмісту розчиненого кисню у водних об'єктах Буського району та оцінка впливу води p. Полтви на стан р. Зх. Буг

Вміст розчиненого кисню у воді р. Полтви - на межі нижнього допустимого його рівня, що є результатом зниження цього показника у воді р. Західний Буг після впадіння р. Полтви. Усі вищенаведені дані та аналіз діаграми даного рисунка, вказують на значну затрату кисню у воді річки Західний Буг, на окислення органічних забрудників, які до неї потрапляють iз водою р. Полтви. Адже фонова ділянка ріки протя- 
гом усіх досліджуваних років має задовільні показники якості води.

\section{Висновки}

Аналіз екологічного стану води у водних об'єктах Буського району свідчить про те, що річка Полтва завдає великої шкоди ріці Західний Буг, куди вона впадає. Фонова ділянка Західного Бугу практично за всіма досліджуваними показниками, відповідає гранично допустимим нормам.

Як показує аналіз моніторингових досліджень, після надходження води р. Полтви, протягом десятків кілометрів, якість води р. Західний Буг, є незадовільною. Максимальне перевищення норм спостерігається у 2017 році: в 2,4 разу - за завислими речовинами, у 8,7 разу - за амонієм, у 8 раз - за фосфатами, у 5,5 разу - за показником БСК 5 , низьким рівнем розчиненого кисню у воді. У 2018 році вода р. Полтви $є$ значно чистішою порівняно із попереднім роком, містить у 2,3 разу менше завислих речовин, у 5,1 разу менше фосфатів та в 1,3 разу - органічних речовин, за показником БСК 5 . Відповідно у цьому ж році спостерігається значне поліпшення екологічного стану р. Західний Буг, після впадіння р. Полтви.

Стан води даних водних об'єктів залежить від ефективності роботи каналізаційних очисних споруд, особливо м. Львова. За останні роки проводяться ремонтні роботи на Львівських КОС: цехи механічного очищення дещо модернізовано, а у найближчій перспективі очікується реконструкція пісколовок та використання мулу для одержання біогазу, що поліпшить екологічну ситуацію, в тому числі й стосовно висвітленої проблеми.

\section{References}

Shandrovych, V.T., Malovanyi, M.S., \& Poliuzhyn, I.P. (2015). Monitorynh efektyvnosti roboty aerotenkiv na Lvivskykh ochysnykh sporudakh. Visnyk Kremenchutskoho natsionalnoho universytetu imeni Mykhaila Ostrohradskoho, 1, 1(90), 1 26-132. http://nbuv.gov.ua/UJRN/Vkdpu_2015_1\%281\%29 22 (in Ukrainian).

Shandrovich, V., \& Mal'ovanyj, M. (2015). Povyshenie urovnja jekologicheskoj bezopasnosti putem uluchshenija raboty kanalizaci-onnyh ochistnyh sooruzhenij (na primere g. L'vova). Ustojchivoe razvitie. Mezhdunarodnyj zhurnal, 3(24), 71-77 (in Russian).

Klymenko, M.O., Vozniuk, N.M., \& Verbetska, K.Iu. (2012). Porivnialnyi analiz normatyviv yakosti poverkhnevykh vod. "Naukovi dopovidi" NUBiP, 8(30): http://nd.nubip.edu.ua/2012_1/12kmo.pdf (in Ukrainian).

Klymenko, M.O., \& Vozniuk, N.M. (2011). Ekolohichnyi stan baseinu riky Zakhidnyi Buh. Visnyk KNU imeni Mykhaila Ostrohradskoho, 1(66), 127-129. http://www.kdu.edu.ua/statti/2011-1-1(66)/127.pdf (in Ukrainian).

Mudryk, O.V., Paraniak, R.P., \& Matsuska, O.V. (2016). Ekolohichni problemy vodnykh resursiv Buskoho raionu. Naukovyi visnyk LNUVMBT im. S.Z. Gzhytskoho, 18, 2(67), 138-143. doi: 10.15421/nvlvet6731 (in Ukrainian).

Iakisnyi stan poverkhnevykh vod Lvivskoi oblasti u 2016 r. Derzhavne ahentstvo vodnykh resursiv Ukrainy, Lvivske oblasne upravlinnia vodnykh resursiv. Zdiisnennia monitorynhu dovkillia: elektron-nyi resurs. Rezhym dostupu: http://lvggme.ucoz.ua (in Ukrainian).

Gumnitsky, J., Sabadash, V., Tyzrbir, G., \& Matsuska, O. (2013). Complex water treatment of agroindustrial complexes before wastewaters discharge into basins of rivers. TRITA-LWR.REPORT 3031-Shveden. Stochgolm, 30-36. https://www.kth.se/polopoly_fs/ 1.651100!/JPSU17P21.pdf.

Stadnichuk, O.M., Leskiv, H.Z., \& Kropyvnytska, L.M. (2013). Monitorynh poverkhnevykh vod Lvivskoi oblasti. Naukovyi chasopys Natsionalnoho pedahohichnoho universytetu imeni M.P. Drahomanova. Seriia 20. Biolohiia. 5, 162-166. http://nbuv.gov.ua/UJRN/ Nchb_020_2013_5_27 (in Ukrainian).

Chaban, Ya.M. (2018). Zvit vyrobnychoi praktyky st. I kursu LNUVMBT imnei S.Z. Hzhytskoho, spetsialnosti 101 "Ekolohiia" OS "Mahistr". Derzhavna ekolohichna inspektsiia u Lvivskii oblasti. Viddil instrumentalno-laboratornoho kontroliu. Lviv (in Ukrainian). 